\title{
The impact of scoliosis detection circumstances on the referral patterns in orthopaedics
}

\author{
Marie Beauséjour*, Marjolaine Roy-Beaudry, Lise Goulet, Charles-Hilaire Rivard, Benoit Poitras, Stefan Parent, \\ Hubert Labelle \\ From 7th International Conference on Conservative Management of Spinal Deformities \\ Montreal, Canada. 20-22 May 2010
}

\section{Introduction}

The literature on efficiency of school scoliosis screening programs (SSSP) discusses the potential benefit of the awareness of health professionals and parents for early detection of scoliosis, as an alternative to mass screening of school children, for proper management of scoliosis patients. This hypothesis was examined in a community without SSSP by analyzing the impact of the professional status of the person involved in scoliosis detection on the appropriateness of referral.

\section{Materials and methods}

345 consecutive patients referred to an orthopaedist for suspected scoliosis at a major hospital in Canada were interviewed to characterize the originator of the detection of their scoliosis: Lay person (family/patient), Allied health (physical therapist, chiropractor, osteopath, sport instructor), General practitioner, and Specialist. Patients were then classified according to the timing of their referral.

\section{Results and discussion}

$136 / 345$ patients (39\%) were considered as referred inappropriately since they presented a Cobb angle lower than $110,61(18 \%)$ met the indications of immediate bracing or surgery and were considered as late referrals. The appropriateness of referral was associated to the professional status of the originator of the scoliosis detection: Chi2 $=17.7, \mathrm{p}=0.007$ (Table 1 ). The presence of scoliosis was first suspected by lay persons in 53\% (181) of cases. Referral profiles were similar for Lay persons and Allied health including late referrals in one fifth of patients. Late referrals were much less likely to

Sainte-Justine Hospital, Montreal, Canada

Full list of author information is available at the end of the article occur in cases detected by physicians, with Specialists presenting the highest rate of appropriate referrals. However, over-referral was more frequent in physicians, especially for General practitioners.

\section{Conclusion}

The professional status of persons involved in scoliosis detection has an impact on the appropriateness of referral. In consequence, increased awareness of scoliosis detection methods by persons involved in child health may favour appropriateness of referral. Guidelines dissemination may be useful to decrease over-referral and improve referral timing in absence of school scoliosis screening programs.

Published: 10 September 2010

doi:10.1186/1748-7161-5-S1-041

Cite this article as: Beauséjour et al:: The impact of scoliosis detection circumstances on the referral patterns in orthopaedics. Scoliosis 2010 5(Suppl 1):O41.

Submit your next manuscript to BioMed Central and take full advantage of:

- Convenient online submission

- Thorough peer review

- No space constraints or color figure charges

- Immediate publication on acceptance

- Inclusion in PubMed, CAS, Scopus and Google Scholar

- Research which is freely available for redistribution

Submit your manuscript at www.biomedcentral.com/submit
Biomed Central 
Table 1 Association between the professional status and appropriateness of referral

\begin{tabular}{lcccc}
\hline & Inappropriate referral & Late referral & Appropriate referral & Total \\
\hline Lay person & $\mathbf{6 3}(34.8 \%)$ & $\mathbf{4 4}(24.3 \%)$ & $\mathbf{7 4}(40.9 \%)$ & $181(100 \%)$ \\
Allied health & $\mathbf{1 5}(35.7 \%)$ & $\mathbf{9}(21.4 \%)$ & $\mathbf{1 8}(42.9 \%)$ & $42(100 \%)$ \\
General practitioner & $\mathbf{2 4}(52.2 \%)$ & $\mathbf{3}(6.5 \%)$ & $\mathbf{1 9}(41.3 \%)$ & $46(100 \%)$ \\
Specialist & $\mathbf{3 4}(44.7 \%)$ & $\mathbf{5}(6.6 \%)$ & $\mathbf{3 7}(48.7 \%)$ & $76(100 \%)$ \\
Total & $136(39.4 \%)$ & $61(17.7 \%)$ & $148(42.9 \%)$ & 345 \\
\hline
\end{tabular}

